\title{
Scopulariopsis brevicaulis
}

National Cancer Institute

\section{Source}

National Cancer Institute. Scopulariopsis brevicaulis. NCI Thesaurus. Code C127746.

A genus of anamorphic fungi in the family Microascaceae. This species is a causative agent of human nail infections and deep fungal infections. 